\title{
Peer Education sebagai Upaya Pencegahan HIV/AIDS
}

\author{
Safitri \\ Prodi D III Kebidanan STIKes Baiturrahim Jambi \\ Email: safitrypipit@gmail.com
}

Submitted : 08/12/2020

Accepted: $31 / 12 / 2020$

Published: 11/01/2021

\begin{abstract}
Adolescents are at the center of HIVIAIDS endemic worldwide, about $50 \%$ of all new cases of HIV occur in youth between age 15 and 24 years. In Indonesia, based on the directorate general of $P 2 P$ the number of HIV positive cases from year to year tends to increase and in 2018 it was reported as many as 46,659 cases. Likewise, the Jambi city, based on data from the health department, the number of cases of HIV / AIDS in adolescents was found in 24 cases (2017) and 13 cases (2018). Peer education is considered a core pillar of HIV prevention efforts in general and has been proven effective in increasing knowledge and promoting changes in attitudes and behavior. Peer education included in Care for Adolescent Health Services (PKPR) program which has a comprehensive approach in the form of promotive/preventive efforts, one of which is health education about HIV and AIDS. Target outcomes expected are: there is an increased knowledge between before and after peer education. The method used is peer education. The results of dedication are an increase in HIV/AIDS knowledge to bring positive changes in the sexual behavior of school adolescents and prevent them from the HIV/AIDS epidemic
\end{abstract}

Keywords: peer education, prevention, HIV/AIDS

Abstrak
Remaja menjadi pusat endemi HIV/AIDS di seluruh dunia, sekitar 50\% dari semua kasus HIV baru terjadi pada remaja antara usia 15 dan 24 tahun. Di Indonesia, berdasarkan Ditjen P2P jumlah kasus HIV positif dari tahun ketahun cenderung meningkat dan pada tahun 2018 dilaporkan sebanyak 46.659 kasus. Begitu juga Kota Jambi, berdasarkan data dinas kesehatan ditemukan jumlah kasus penderita HIV/AIDS pada remaja 24 kasus (2017) dan 13 kasus (2018). Peer education dianggap sebagai pilar inti dari upaya pencegahan HIV secara umum dan telah terbukti efektif dalam meningkatkan pengetahuan dan mempromosikan perubahan sikap dan perilaku. Peer education masuk dalam program Pelayanan Kesehatan Peduli Remaja (PKPR) yang memiliki pendekatan komprehensif berupa upaya promotif/preventif salah satunya pembekalan kesehatan tentang HIV dan AIDS. Target luaran yang diharapkan peningkatan pengetahuan antara sebelum dan setelah peer education. Metode yang digunakan adalah peer education. Hasil pengabdian terdapat peningkatan pengetahuan HIV/AIDS untuk membawa perubahan positif dalam perilaku seksual remaja sekolah dan mencegah mereka dari epidemi HIV/AIDS

Kata Kunci: peer education, pencegahan, HIV/AIDS

\section{PENDAHULUAN}

Remaja menjadi pusat endemi HIV/AIDS di seluruh dunia, sekitar $50 \%$ dari semua kasus HIV baru terjadi pada remaja antara usia 15 dan 24 tahun. Studi di berbagai negara bagian Afrika menunjukkan bahwa baik di luar sekolah maupun di sekolah, remaja berisiko terlibat dalam perilaku seksual. Tingkat pengetahuan tentang HIV/AIDS pada remaja di negara bagian Afrika rendah, yaitu remaja putri $(36 \%)$ dan remaja putra (28\%). Meskipun remaja memiliki pengetahuan tentang langkah-langkah pencegahan AIDS, tidak banyak dari mereka yang melakukan pencegahan. Sebuah penelitian di Ethiopia menunjukkan bahwa hanya 58\% remaja yang tidak melakukan hubungan seksual sebagai salah satu cara mencegah HIV. Remaja yang melakukan hubungan seksual dengan teman laki-laki/perempuan, hanya $58,5 \%$ yang menggunakan kondom dan 32,6\% yang di tes HIV (Menna dkk, 2015). 
Estimasi jumlah orang dengan HIV di Indonesia pada tahun 2018 sebanyak 641.675 orang dengan jumlah infeksi baru sebanyak 46.372 orang dan kematian sebanyak 38.734 orang. Jumlah kasus HIV positif yang dilaporkan dari tahun ketahun cenderung meningkat dan pada tahun 2018 dilaporkan sebanyak 46.659 kasus. Sampai dengan tahun 2018 jumlah kasus HIV yang dilaporkan sebanyak 327.282 kasus. Persentase kasus HIV positif dan AIDS tahun 2018 pada laki-laki lebih besar dibandingkan perempuan. Penderita HIV positif pada laki-laki sebesar $63,8 \%$ dan pada perempuan sebesar $36,2 \%$. Sedangkan penderita AIDS pada laki-laki sebesar 67,2\% dan pada perempuan sebesar 32,8\%. Proporsi terbesar kasus HIV dan AIDS masih pada penduduk usia produktif (15-49 tahun), dimana kemungkinan penularan terjadi pada usia remaja. HIV dapat ditularkan melalui hubungan seks, tranfusi darah, penggunaan jarum suntik bergantian dan penularan dari ibu ke anak (perinatal) (Kemenkes, 2019).

Jumlah kasus penderita HIV/AIDS pada remaja di Kota Jambi tahun 2017, dari 1.088 orang yang berkunjung, penderita HIV positif pada laki-laki sebanyak 14 kasus (usia 20-24 tahun) dan pada perempuan sebayak 10 kasus (1 kasus usia 5-14, 1 kasus usia 15-19 dan 8 kasus usia 20-24 tahun). Sedangkan pada tahun 2018, dari 386 orang yang berkunjung, penderita HIV positif pada laki-laki sebanyak 11 kasus (4 kasus usia 15-19 tahun dan 7 kasus usia 20-24 tahun) dan pada perempuan sebayak 2 kasus (usia 20-24 tahun) (Dinkes Kota, 2019).

HIV (Human Immunodeficiency Virus) adalah virus yang menyerang sistem kekebalan tubuh. Infeksi tersebut menyebabkan penderita mengalami penurunan kekebalan sehingga sangat mudah untuk terinfeksi berbagai macam penyakit lain. AIDS (Acquired Immuno Deficiency Syndrome) yaitu sekumpulan gejala berkurangnya kemampuan pertahanan diri yang disebabkan oleh masuknya virus HIV. Program pengendalian HIV di Indonesia bertujuan untuk: 1.) Menurunkan hingga meniadakan infeksi baru; 2.) Menurunkan hingga meniadakan kematian terkait AIDS; 3.) Menurunkan stigma dan diskriminasi (Kemenkes, 2019).

Peer education dianggap sebagai pilar inti dari upaya pencegahan HIV secara umum dan telah terbukti efektif dalam meningkatkan pengetahuan dan mempromosikan perubahan sikap dan perilaku. Peer education dengan dukungan para guru didorong melakukan pendekatan inovatif untuk mengatasi kebutuhan kesehatan produktif rekan sebayanya, terutama tentang HIV/AIDS. Remaja yang percaya pada teman sebaya tidak cenderung tidak akan terlibat dalam hubungan seksual. Peer education sangat efektif sebagai sumber informasi, keterampilan dan memotivasi untuk melakukan perilaku yang baik (Adeomi, 2014).

Peer education adalah salah satu strategi efektif untuk mengubah perilaku pada remaja, memberikan kesempatan belajar yang unik untuk mempromosikan perilaku kesehatan (Ghasemi, 2019). Peer education adalah strategi dimana individu dari kelompok sasaran memberikan informasi, pelatihan, atau sumber daya kepada rekan-rekan mereka. Ini telah menjadi metode pendidikan kesehatan yang populer untuk pencegahan HIV sejak 1980-an, mungkin karena interaksi positif yang ditimbulkan antara teman sebaya. Intervensi peer education secara signifikan terkait dengan peningkatan pengetahuan HIV, berkurangnya pengguna narkoba suntikan dan penggunaan kondom, serta mempengaruhi perubahan perilaku kesehatan dan mengatasi pandemi HIV/AIDS (Menna, 2015).

Di indonesia, peer education masuk dalam program Pelayanan Kesehatan Peduli Remaja (PKPR) yang memiliki pendekatan komprehensif berupa upaya promotif/preventif melalui pembinaan peer education salah satunya pembekalan kesehatan tentang HIV dan AIDS (Kemenkes RI, 2014). Penerapan peer education di sekolah menengah dapat memainkan peran penting untuk membawa perubahan positif dalam perilaku seksual remaja sekolah dan mencegah mereka dari epidemi mematikan, HIV/AIDS (Menna, 2015).

Berdasarkan data Dinas Pendidikan Kota Jambi, SMA Negeri 8 memiliki jumlah siswa terbanyak pada tahun akademik 2018/2019 yaitu 1.726 siswa $(14,9 \%)$ dari seluruh SMA Negeri di Kota Jambi. Survey pendahuluan terhadap 10 siswa, menunjukkan bahwa 70\% siswa memiliki pengetahuan kurang dan $30 \%$ siswa memiliki pengetahuan baik tentang HIV/AIDS. 60\% siswa mengaku sudah pernah pacaran, pernah melakukan ciuman pipi, pelukan dan $40 \%$ siswa memiliki perilaku baik dalam pencegahan HIV/AIDS. Serta program 
peer education yang ada di SMA tersebut sudah terbentuk tetapi belum berjalan secara optimal.

Berdasarkan paparan diatas maka penulis tertarik mengangkat judul "peer education sebagai upaya pencegahan HIV/AIDS di SMA Negeri 8 Kota Jambi" untuk membawa perubahan positif dalam perilaku seksual remaja sekolah dan mencegah mereka dari epidemi HIV/AIDS.

\section{TARGET DAN LUARAN}

Target dalam kegiatan pengabdiaan kepada masyarakat ini adalah melakukan peer education tentang HIV/AIDS pada siswa SMA N 8 Kota Jambi. Adapun luaran dalam kegiatan pengabdian kepada masyarakat ini adalah publikasi pada jurnal ilmiah dan meningkatkan pengetahuan siswa tentang HIV/AIDS dengan harapan membawa perubahan positif dalam perilaku yang berhubungan dengan kesehatan seksual remaja sekolah dan mencegah mereka dari epidemi HIV/AIDS.

\section{METODE PELAKSANAAN}

Pengabdian kepada masyarakat ini dilaksanakan pada bulan November 2019 di SMA N 8 Kota Jambi. Sasaran kegiatan ini adalah siswa di SMA Negeri 8 Kota Jambi. Kegiatan pengabdian kepada masyarakat ini, mendapat rekomendasi dari Kepala Sekolah dan Guru Bimbingan Konseling untuk memberikan informasi tentang HIV/AIDS melalui metode peer education kepada siswa yang telah terpilih menjadi konselor sebaya menggunakan media leaflet. Peer education yang telah dilakukan merupakan kegiatan untuk menyampaikan informasi tentang HIV/AIDS meliputi pengertian AIDS, penularan HIV, tanda dan gejala HIV-AIDS, kelompok perilaku resiko tinggi terinfeksi HIV, pencegahan HIV, dan hal-hal yang perlu diperhatikan bila disekitar kita ada yang positif HIV-AIDS.

Tahapan kegiatan pengabdian kepada masyarakat meliputi:

1. Mengkaji dan menganalisis data

2. Mengidentifikasi masalah

3. Menyusun rencana kegiatan

4. Menyusun SAP, materi, instrumen preposttest serta mendesain leaflet

5. Mengurus izin lokasi kegiatan

6. Melakukan pretest
7. Melakukan peer education meliputi memberikan materi tentang HIV/AIDS

8. Melakukan posttest

9. Melakukan monitoring dan evaluasi

\section{HASIL DAN PEMBAHASAN}

Pelaksanaan kegiatan pengabdian kepada masyarakat berjalan sesuai dengan rencana yang disusun. Kegiatan ini dilakukan bersamaan dengan jadwal classmeeting semester ganjil di SMA Negeri 8 Kota Jambi. Dalam pelaksanaan kegiatan ini Tim difasilitasi oleh guru bimbingan konseling untuk mengumpulkan dan memilih siswa setiap kelas untuk dijadikan konselor sebaya dalam satu ruangan kelas di SMA tersebut.

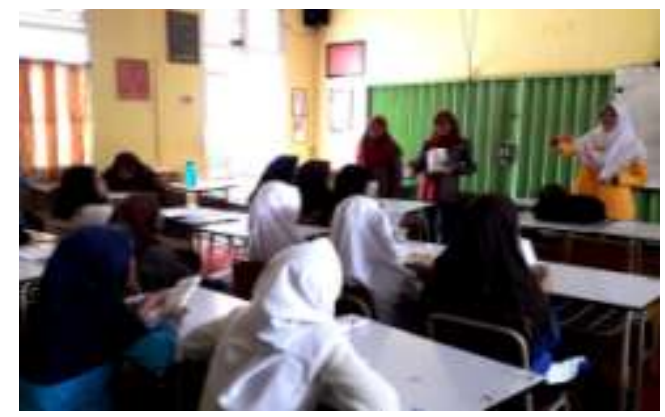

Gambar.1 Peer education dengan memberikan materi HIV/AIDS menggunakan leaflet

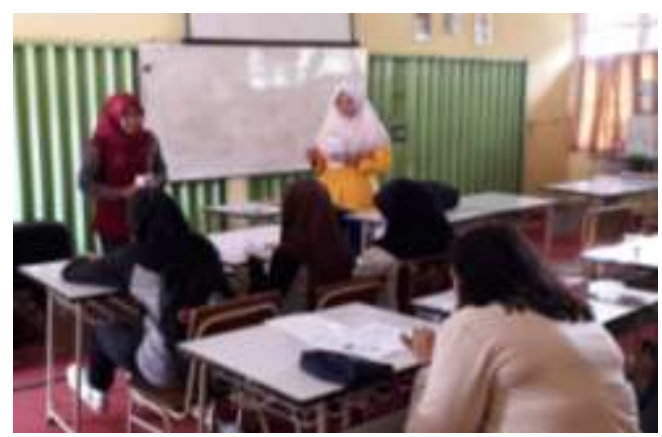

Gambar.2 Diskusi dalam peer education tentang HIV/AIDS

Sebelum kegiatan peer education tentang HIV/AIDS, 50\% siswa tidak mengetahui pengertian AIDS dengan benar, 60\% siswa tidak dapat menginformasikan penularan HIV, $65 \%$ siswa tidak dapat menyebutkan tanda dan gejala HIV-AIDS, $60 \%$ siswa tidak dapat menerangkan kelompok perilaku resiko tinggi terinfeksi HIV, 60\% siswa tidak dapat menjabarkan pencegahan HIV, dan 55\% siswa tidak dapat menginformasikan hal-hal yang perlu diperhatikan bila disekitar kita ada yang 
positif HIV-AIDS. Peer eduation sebagai strategi perubahan perilaku yang efektif diharapkan dapat memberikan dampak pada perubahan pengetahuan tentang HIV/AIDS.

Setelah dilakukan peer education tentang HIV/AIDS, $85 \%$ siswa mampu menjelaskan pengertian AIDS dengan benar, $75 \%$ siswa menginformasikan transfusi darah, hubungan seksual dan benda-benda tajam yang tidak disterilkan sebagai penularan HIV, 70\% siswa mampu menyebutkan tanda dan gejala HIVAIDS, $75 \%$ siswa mampu menerangkan kelompok perilaku resiko tinggi terinfeksi HIV, $75 \%$ siswa mampu menjabarkan pencegahan HIV, dan $80 \%$ mampu menginformasikan halhal yang perlu diperhatikan bila disekitar kita ada yang positif HIV-AIDS. Hasil tersebut menunjukkan adanya peningkatan pengetahuan siswa setelah dilakukan peer education tentang HIV/AIDS. Siswa yang memiliki pengetahuan baik akan membawa perubahan positif dalam perilaku seksual remaja sekolah dan mencegah mereka dari epidemi HIV/AIDS.

Kegiatan pengabdian kepada masyarakat ini menunjukkan adanya peningkatan pengetahuan siswa setelah dilakukan peer education, hal ini karena pada peer education penyampai informasi adalah teman sebaya, yang mampu berkomunikasi, mampu mempengaruhi teman sebayanya, punya hubungan pribadi yang baik dengan teman sebayanya, punya pemahaman lingkungan sosial dan budaya teman yang baik, punya pengetahuan tentang HIV/AIDS sehingga informasi dapat dengan mudah diterima, mereka mampu mengajak dan mengubah sikap teman sebayanya untuk berperilaku secara positif mengenai masalahmasalah yang terjadi sekitar penyakit HIV/AIDS. Selain itu, informasi tentang HIV/AIDS yang dimiliki siswa juga berasal dari sumber lain seperti, media massa dan situs web.

Hasil tersebut sejalan dengan penelitian yang dilakukan oleh Adeomi dkk (2014) berjudul Evaluation of the Effectiveness of Peer Education inImproving HIV Knowledge, Attitude, and Sexual Behaviours among InSchool Adolescents in Osun State, Nigeria, terhadap 48 siswa SMA yang berusia 10-19 tahun. Hasil analisis bivariat menunjukkan bahwa terdapat perbedaan yang bermakna antara pengetahuan, sikap dan perilaku seksual remaja setelah dilakukan peer education $(p<0,05)$. Peningkatan pengetahuan dan sikap dari $50 \%$ menjadi $86,7 \%$ dan dari $49 \%$ menjadi $85,6 \%$. Peer education efektif dalam meningkatkan pengetahuan, sikap dan perilaku pencegahan terhadap HIV/AIDS pada remaja di lingkungan sekolah.

Peer education adalah sumber informasi yang dapat membantu remaja sekolah tentang HIV/AIDS. Penyampaian informasi dilakukan oleh teman sebaya yang sudah mendapat pelatihan sebelumnya. Pendidik sebaya ini adalah orang yang dipilih mempunyai sifat kepemimpinan dalam membantu orang lain. Di samping itu ada syarat tertentu yang harus dimiliki pendidik sebaya, di antaranya mampu berkomunikasi, mampu mempengaruhi teman sebaya, punya hubungan pribadi yang baik, mampu mendengarkan pendapat orang lain, punya pengetahuan tentang HIV/AIDS dan punya waktu yang cukup (Kemenkes, 2014).

Peer education juga membuat suasana diskusi menjadi lebih terbuka dan tidak kaku. Hal-hal yang dianggap tabu untuk didiskusikan khususnya mengenai seks dan HIV/AIDS itu sendiri ketika informasi diberikan oleh guru menjadi tidak tabu lagi ketika informasi diberikan oleh teman sebayanya. Hal ini akan menarik minat mereka untuk mendengarkan, bertanya, dan menambah pengetahuan mereka tentang HIV/AIDS. Pada remaja di sekolah menengah, teman sebaya mempunyai pengaruh yang sangat tinggi dalam perubahan perilaku. Mereka akan cenderung memilih perilaku yang sama dengan anggota teman sebayanya, agar mereka tidak dianggap asing oleh kelompoknya (Muadz dkk, 2014).

Penelitian serupa oleh Mohammed Ali dkk (2015) berjudul The Effect of AIDS Peer Health Education on Knowledge, Attitudes, and Practices of Secondary School Students in Khartoum, Sudan, terhadap 200 siswa yang dipilih dari 10 sekolah (20 siswa masingmasing sekolah) yang dilakukan secara bertahap. Hasil analisis bivariat menunjukkan perbedaan yang bermakna antara pengetahuan, sikap dan praktik remaja setelah dilakukan peer education tentang AIDS $(\mathrm{P}<0,05)$. Peer education meningkatkan pengetahuan dari $75,5 \%$ menjadi $83,2 \%$. Peer education merupakan pendekatan yang efektif untuk memberitahu siswa tentang perilaku seksual yang tidak aman terkait dengan HIV/AIDS.

Peer education menggunakan orang-orang dari kelompok sebaya dimaksudkan untuk 
mempermudah penyampaian pesan-pesan kepada kelompok sasaran. Seseorang akan lebih bersedia mendengarkan jika pesan-pesan disampaikan oleh orang yang berasal dari lingkungan mereka sendiri, atau memiliki latar belakang sosial yang kurang lebih sama. Dalam kondisi seperti ini, motivasi untuk menuruti ajakkan dan aturan kelompok sebaya cukup tinggi pada siswa, karena siswa menganggap bahwa aturan kelompok sebaya merupakan yang paling benar dan siswa berusaha melakukan berbagai usaha agar diterima dan diakui keberadaannya dalam kelompok (Haerana dkk, 2015).

Metode peer education memang harus mampu mempengaruhi pengetahuan siswa. Hal ini karena membicarakan masalah HIV/AIDS tidak terlepas dari masalah seks. Membicarakan seks pada remaja masih malu dan dianggap tabu, namun bila disampaikan oleh teman sebaya maka teman sebagai penerima informasi tidak malu, tidak sungkan, dan mau bertanya dalam rangka menambah pengetahuan mereka. Dalam kondisi inilah saat rentan mereka terhadap dampak pergaulan negatif. Siswa harus dibawa pada karakter tangguh dan mandiri yang dibangun dengan semangat membangun bangsa. Semangat dibutuhkan untuk menstimulus agar siswa mampu menunjukkan kontribusi positif dalam pembangunan bangsa. Semangat ini berupa keunggulan khas, dapat diandalkan, serta daya tahan dalam kesulitan dan arus budaya yang menyesatkan. Terpenting juga modal moralitas untuk tetap menjaga agar jangan sampai terjerumus dalam perilaku seks bebas yang mengancam terjadinya pengrusakan generasi penerus kepemimpinan bangsa.

Peer education sangat bermanfaat bagi program penanggulangan HIV dan AIDS, karena aspek informasi dan pengetahuan berperan bagi seseorang untuk mencegah dirinya terkena infeksi, dimana pengetahuan, sikap, dan perilaku seksual memiliki keterkaitan erat. Banyak kekeliruan informasi berkenaan dengan HIV dan AIDS, sehingga merupakan mitos-mitos yang mempengaruhi persepsi seseorang tentang penyakit tersebut dan/atau tentang penderita. Untuk itu, diperlukan peer educator terlatih untuk membantu penyampaian informasi dan pengetahuan yang benar, sekaligus membangun kewaspadaan terhadap risiko penularan HIV dan AIDS dikalangan kelompok sebaya yang menjadi sasaran program (Haerana dkk, 2015).

\section{KESIMPULAN DAN SARAN}

\section{Kesimpulan}

Pelaksanaan kegiatan pengabdian kepada masyarakat yang dilakukan melalui peer education di SMA N 8 Kota Jambi mampu meningkatkan pengetahuan untuk membawa perubahan positif dalam perilaku seksual remaja sekolah dan mencegah mereka dari epidemi HIV/AIDS.

\section{Saran}

Diharapkan kepada pihak sekolah dapat menjadikan metode peer education ini sebagai metode pendidikan kesehatan di lingkungan sekolah dan menghimbau pada PIK-R di SMA $\mathrm{N} 8$ untuk dapat menyebarkan informasi ke teman-temannya dalam upaya deteksi dini masalah-masalah kesehatan pada remaja.

\section{UCAPAN TERIMAKASIH}

Tim pengabdian masyarakat mengucapkan terima kasih yang sebesar-besarnya kepada STIKes Baiturrahim Jambi atas bantuan dana dan fasilitas surat izin. Serta Kepala Sekolah dan Guru Bimbingan Konseling yang telah memfasilitasi dan memberikan izin tempat pengabdian kepada masyrakat ini, sehingga kegiatan pengabdian masyarakat ini dapat berjalan dengan lancar sesuai dengan waktu yang telah ditentukan.

\section{DAFTAR PUSTAKA}

Adeomi AA, Adeoye OA, Asekun-Olarinmoye EO, Abodunrin OL, Olugbenga-Bello AI, dkk. Evaluation of the Effectiveness of Peer Education inImproving HIV Knowledge, Attitude, and Sexual Behavioursamong In-School Adolescents in Osun State, Nigeria. AIDS Research and Treatment. 2014:110.

Ghasemi V, Simbar M, Fakari FR, Naz MSG, Kiani Z. The Effect of Peer Education on Health Promotion of Iranian Adolescents: A Systematic Review. IJP. 2019 Mar;7(3):9139-57.

Haerana T, Salfiantini, Ridwan M. Peningkatan Pengetahuan Komprehensif HIV dan AIDS Melalui Peer Group. Jurnal MKMI. 2015 Jun:132-8. 
Kementerian Kesehatan RI. 2019. Profil Kesehatan Indonesia 2018. Kesehatan Kementerian Kesehatan RI. Jakarta.

Kementrian Kesehatan RI. 2014. Modul Pelatihan Pelayanan Kesehatan Peduli Remaja (PKPR) Bagi Konselor Sebaya. Direktorat Bina Kesehatan Anak, Direktorat Jendral Bina Gizi dan KIA Kementrian Kesehatan RI.

Menna T, Ali A, Worku A. Effects of peer education intervention on HIV/AIDS related sexual behaviors ofsecondary school students in Addis Ababa,Ethiopia: a quasi-experimental study. Reproductive Health. 2015;84(12):1-8.

Mohammed Ali MH, Osman OB, M.Ibrahim MAE, Mohammed Ahmed WA. The Effect of AIDS Peer Health Education on Knowledge, Attitudes, and Practices of Secondary School Students in Khartoum, Sudan. AIMS Publich Health. 2015;2(4):718-26. DOI:10.3934/publichealth.2015.4.718.

Muadz MM, Dahlan, Dewi A. 2014. Kesehatan Reproduksi Remaja dan Wanita. Salemba Medika. Jakarta. 